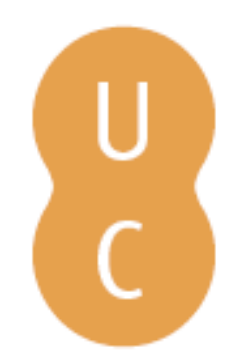

\title{
pommalina
}

\section{Simulations of surface fire propagating under a canopy: flame angle and intermittency}

\author{
Autor(es): $\quad$ Sutherland, Duncan; Philip, Jimmy; Ooi, Andrew; Moinuddin, Khalid \\ Publicado por: Imprensa da Universidade de Coimbra \\ URL \\ persistente: URI:http://hdl.handle.net/10316.2/44681 \\ DOI: $\quad$ DOI:https://doi.org/10.14195/978-989-26-16-506_164 \\ Accessed : $\quad$ 26-Apr-2023 11:46:40
}

A navegação consulta e descarregamento dos títulos inseridos nas Bibliotecas Digitais UC Digitalis, UC Pombalina e UC Impactum, pressupõem a aceitação plena e sem reservas dos Termos e Condições de Uso destas Bibliotecas Digitais, disponíveis em https://digitalis.uc.pt/pt-pt/termos.

Conforme exposto nos referidos Termos e Condições de Uso, o descarregamento de títulos de acesso restrito requer uma licença válida de autorização devendo o utilizador aceder ao(s) documento(s) a partir de um endereço de IP da instituição detentora da supramencionada licença.

Ao utilizador é apenas permitido o descarregamento para uso pessoal, pelo que o emprego do(s) título(s) descarregado(s) para outro fim, designadamente comercial, carece de autorização do respetivo autor ou editor da obra.

Na medida em que todas as obras da UC Digitalis se encontram protegidas pelo Código do Direito de Autor e Direitos Conexos e demais legislação aplicável, toda a cópia, parcial ou total, deste documento, nos casos em que é legalmente admitida, deverá conter ou fazer-se acompanhar por este aviso.

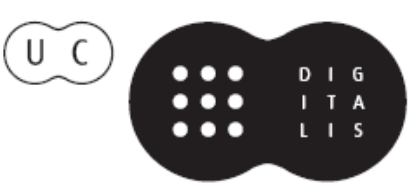




\section{ADVANCES IN}

\section{FOREST FIRE RESEARCH}

\section{8}

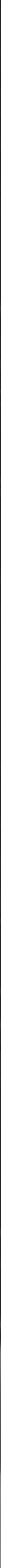


Short contribution - Fire Management

Simulations of surface fire propagating under a canopy: flame angle and intermittency

\author{
Duncan Sutherland*1,4; Jimmy Philip²; Andrew Ooi²; Khalid Moinuddin ${ }^{3,4}$ \\ ${ }^{I}$ School of Physical, Environmental, and Mathematical Sciences, UNSW Canberra, Canberra, Australia, \\ \{duncan.sutherland@adfa.edu.au*\} \\ ${ }^{2}$ Department of Mechanical Engineering, Melbourne School of Engineering, University of Melbourne, \\ Melbourne Australia., \{jimmyp@unimelb.edu.au,a.ooi@unimelb.edu.au\} \\ ${ }^{3}$ Institute for Sustainable Industries and Liveable Cities, Victoria University, Melbourne, Australia \\ \{khalid.moinuddin@vu.edu.au\} \\ ${ }^{4}$ Bushfire and Natural Hazards Cooperative Research Centre, Melbourne, Australia
}

\begin{abstract}
We conduct physics-based simulations of a wind driven surface fire entering, propagating through, and leaving a region of aerodynamic drag. This is an idealised model of a real-world grassfire propagating through a short canopy such as a stand of trees. The study is motivated by the need to understand how fires entering forested regions adjust to the lower wind speed inside the forest. This will lead to more informed operational modelling practices and predictions of fire spread. In these simulations the driving open $(10 \mathrm{~m})$ wind speed is varied from $1 \mathrm{~ms}^{-1}$ to $10 \mathrm{~ms}^{-1}$. For lower driving wind speeds the rate-of-spread of the fire is largely unaffected by the canopy, however, for the higher driving wind speeds the fire appears to transition from a wind-driven mode, characterised by a low flame angle to a buoyancy-driven mode, characterised by a nearly vertical flame.
\end{abstract}

Keywords: Physics-based fire simulation, surface fire, tree canopies, flame intermittency, non-quasisteady fires

\title{
1. Characterising fire spread
}

We report on a physics-based simulation study of a surface fire in a uniform fuel bed propagating through a region of aerodynamic drag. This is an idealised model of a wildfire entering, propagating through a canopy, and leaving the canopy region (c.f. figure 1). Wildfires may be broadly classified into two modes: wind-driven fires, which are dominated by the driving wind characterised by an elongated flame at an acute angle to the ground; and buoyancy-driven fires, which are dominated by the dynamics of the plume and characterised by a vertical flame. Fires can also propagate in an intermittent surge-stall manner (Dold 2011) where the fire oscillates between the wind-driven and buoyancy-driven modes. The time-averaged driving wind field associated with a fire propagating from open grassland to a forested region and eventually back to open grassland will vary in space. Simulations of flow through isolated tree canopies surrounded by clearings have been conducted in the absence of a fire (eg Kanai-Shuring and Raasch (2017)). Simulations (Keifer et al. 2015) and measurements (Seto et al. 2014) of the mean and turbulence statistics from downstream of low intensity surface fires within canopies have also been conducted. The simulations of Keifer et al. involved modelling the fire as a surface temperature anomaly instead of explicitly simulating fuel combustion as done here. Seto et al. measured the temperature and vertical velocity fluctuations as a surface fire progressed under a canopy for similar sized fires as simulated here (and detailed in section 2). The spatial development of the time-averaged wind field over an isolated canopy is relatively straightforward to simulate by modelling the tree canopy as a region of aerodynamic drag which depends on the Leaf Area Density (LAD) of the forest. We hypothesise that the fire will transition between the wind driven mode in the open grassland to a buoyancy dominated fire in the canopy, and 
then back to a wind driven mode downstream of the canopy. The surge-stall regime is expected to occur in regions around the transition between these two modes. The aim of the present study is to use full-physics-based simulations of an idealised model fire to examine how and where the fire transitions between the wind driven and buoyancy modes as the fire progresses through the canopy.

\section{Idealised Model}

A series of physics-based three-dimensional large-eddy simulations of a grass fire entering, propagating under, and leaving a short tree canopy, without burning the canopy itself are conducted varying only the magnitude of the driving wind speed. The well-known physics-based fire simulation Fire Dynamics Simulator (FDS, McGrattan et al. 2013) is used for this study. FDS uses a Large Eddy Simulation (LES) methodology for the gas phase, a mixture-fraction combustion model, a linear model of the fuel pyrolysis, and accounts for heat transfer by conduction, convection, and radiation. Mell et al. (2007) performed simulations of quasi-steady open grassfires and validated against experimental data. To reduce the computational effort and as a first approximation to a general spanwise varying fire-front, we considered a narrow domain. As such, the fire front is homogeneous in the $y$-direction, resulting quasi-two-dimensional simulation. The fuel along the ground is kept constant in the canopy and non-canopy regions and the burning of the tree canopy is not considered. Therefore, the canopy acts only as a region of aerodynamic drag. A schematic showing the simulation domain, the ignition line, and the canopy is shown in Figure 1. The idealisations in this model are used to isolate the effect of the aerodynamic drag of the canopy upon the fire dynamics. The burning of the canopy may be considered in a later study. The parameter space investigated here is variation of inlet wind speed. The inlet wind speed at $10 \mathrm{~m}$ height is varied between $u(x=0, z=10)=1,2,4,6,8$, and $10 \mathrm{~ms}^{-1}$. All other parameters are held constant.

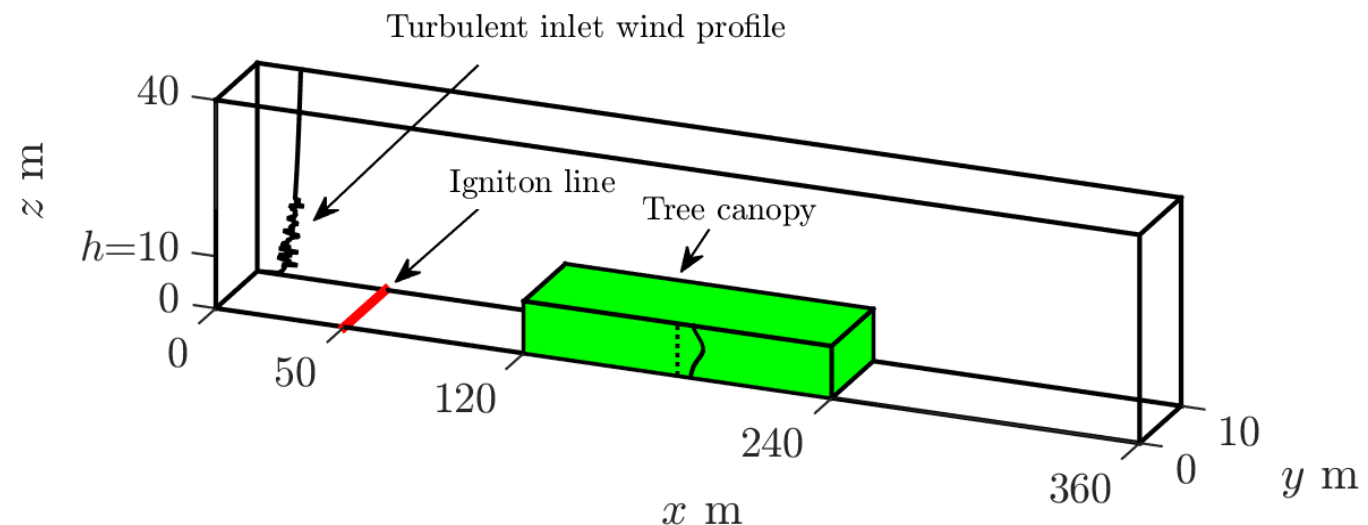

Figure 1 - Simulation domain showing the location of the model tree canopy, the turbulent inlet wind conditions, and the fire ignition line. The profile of leaf area density is also shown.

The inlet wind speed is simulated using the synthetic eddy method (SEM) similar to Jarrin et al. (2006). The SEM introduces artificial turbulence at the inlet to ensure fast development of a realistic boundary-layer flow. A mean profile, in this case a logarithmic profile, is specified at the inlet and randomly generated eddies sampled from a distribution with specified length and velocity scales are superimposed upon the mean profile. The SEM leads to the development of a realistic turbulent loglayer after approximately $50 \mathrm{~m}$. (Pavlidis et al. 2010). Contours of the $u$-velocity and $w$-velocity for the $6 \mathrm{~ms}^{-1}$ driving wind case and $u$-velocity as a function of $x$ at $z=2$ and $10 \mathrm{~m}$ for all cases are shown in Figure 2. 

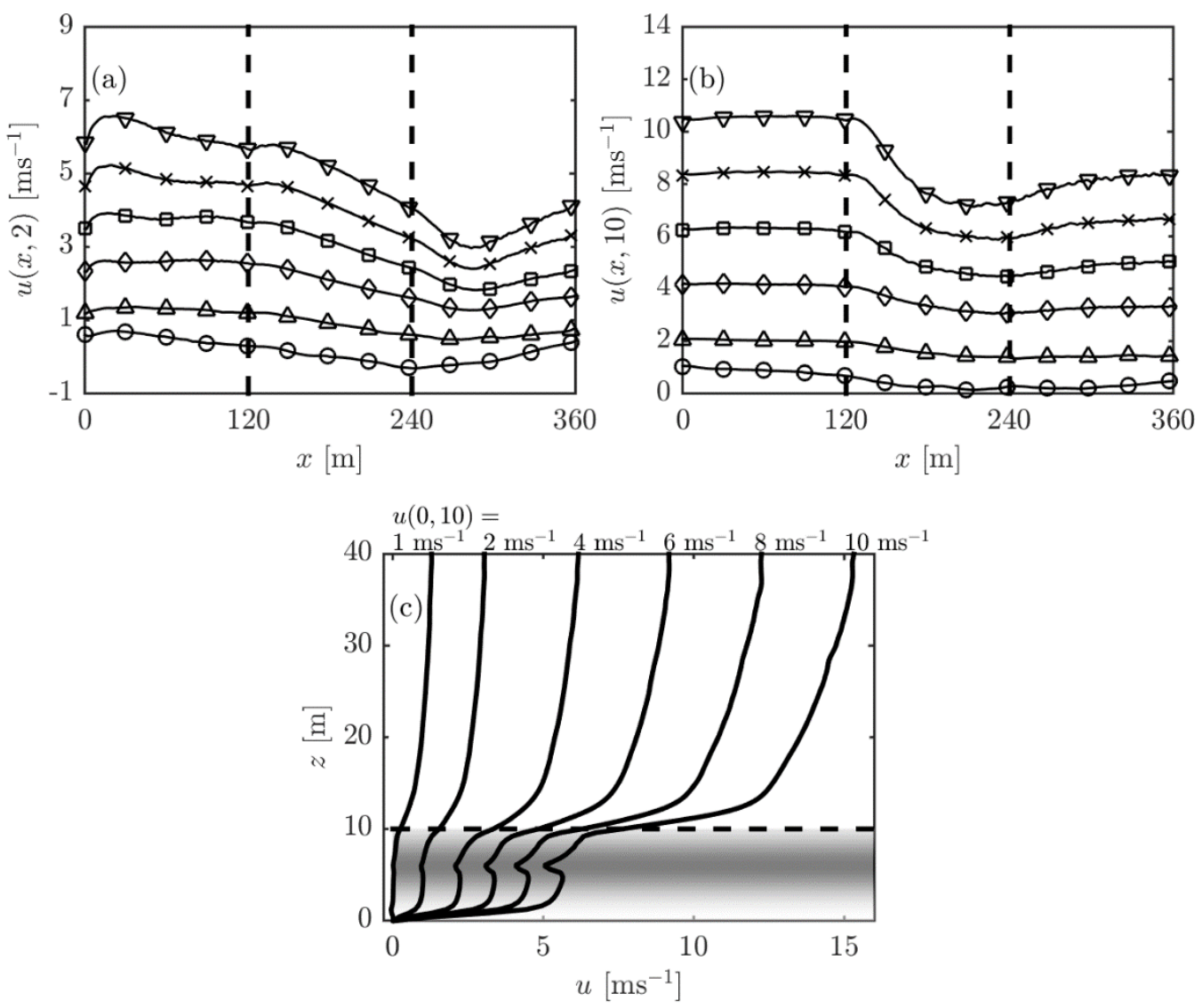

Figure 2 - (a) The $u(x, z)$ at $z=2 \mathrm{~m}(c)$ and $(b) u(x, z)$ at $z=10 \mathrm{~m}(c)$ u-velocities at $x=180 \mathrm{~m}$ all cases. The canopy edge is represented by the dotted line. The LAD profile is represented by the grey shading. Recall the height of the canopy is $10 \mathrm{~m}$ and the significant drop in velocity is due to the canopy. The minor differences between the actual and desired inlet velocity is due to the imposition of a turbulent boundary condition there.

\section{Simulated fire fronts and flame angle}

Because the fire maintains a straight front the results of the fire spread may be averaged across the domain. The contours of boundary temperature are shown in Figure 3 to visualise the fire spread. For $u(0,10)<4 \mathrm{~ms}^{-1}$ the propagation is largely unaffected by the presence of a canopy. In the higher driving velocity cases the rate-of-spread decreases suddenly near the downstream edge of the canopy. The $x$-distance of the transition point occurs later for higher driving wind speeds. The pyrolysis and drying regions narrow as the rate-of-spread of the fire decreases. The flame angle as a function of location is shown in Figure 4. For driving wind speeds $u(0,10)>2 \mathrm{~ms}^{-1}$ the flame angle undergoes a dramatic jump towards the downstream edge of the canopy and the flame angle also exhibits significant oscillations in the downstream region. In the highest driving wind speed case $u(0,10)=10 \mathrm{~ms}^{-1}$ the flame angle oscillates significantly over the whole domain. 


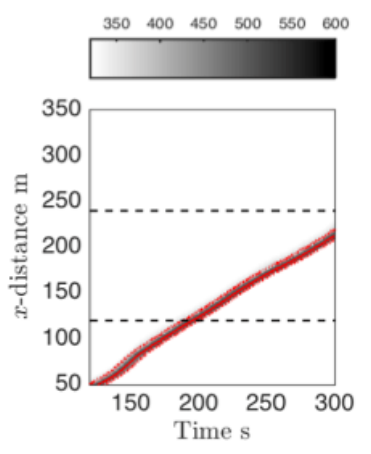

(a) $u_{10}(0)=1 \mathrm{~ms}^{-1}$

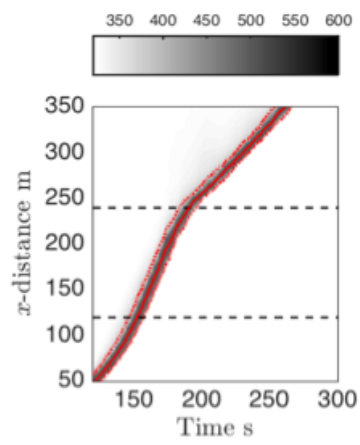

(d) $u_{10}(0)=6 \mathrm{~ms}^{-1}$

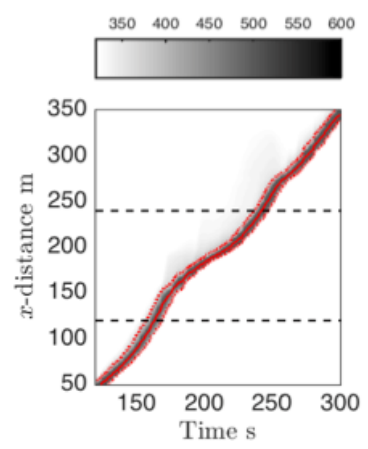

(b) $u_{10}(0)=2 \mathrm{~ms}^{-1}$

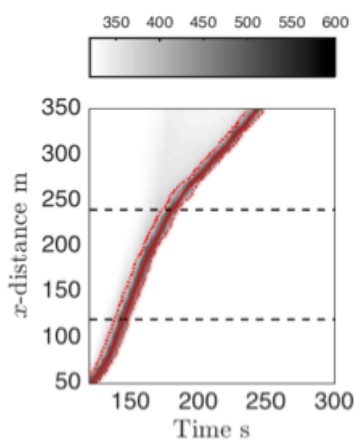

(e) $u_{10}(0)=8 \mathrm{~ms}^{-1}$

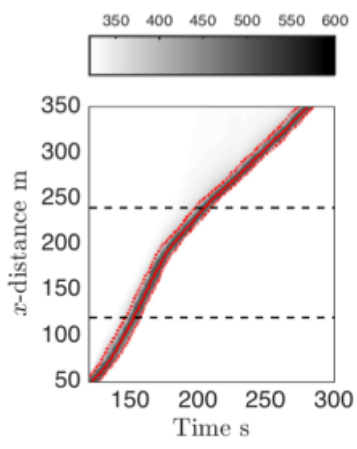

(c) $u_{10}(0)=4 \mathrm{~ms}^{-1}$

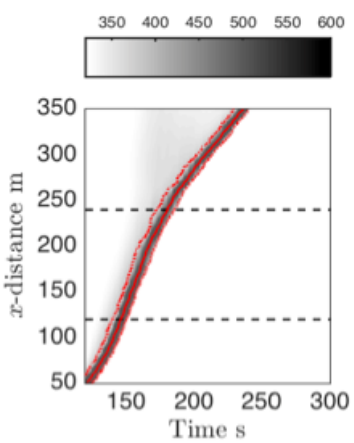

(f) $u_{10}(0)=10 \mathrm{~ms}^{-1}$

Figure 3 - Visualisations of the fire. Contours of boundary temperature (grey shading), the fire front location $x *($ solid red), the drying region (thin red dotted), and the canopy region (horizontal thick black dashed). Pyrolysis occurs in the dark shaded region and preheating of the fuel bed is also apparent.
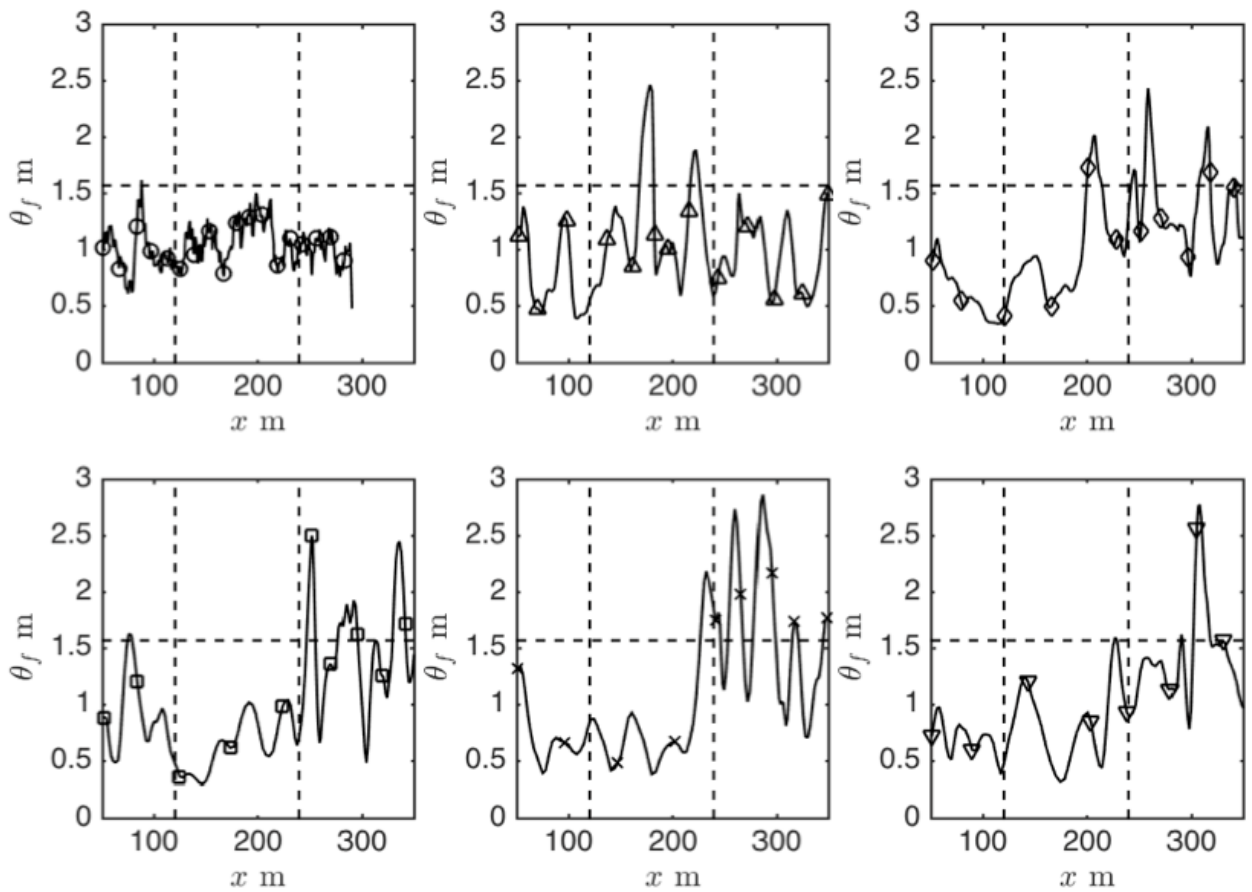

Figure 4 - Flame angle (radians) as a function of $x$-location for the cases as shown. The canopy boundaries are shown as vertical dashed lines and the horizontal line represents an angle of $90^{\circ}$. Symbols: $($ circles $) u(0,10)=1 \mathrm{~ms}$ ${ }^{1}$,(triangles) $2 \mathrm{~ms}^{-1}$,(diamonds) $4 \mathrm{~ms}^{-1}$, (squares) $6 \mathrm{~ms}^{-1}$, (crosses) $8 \mathrm{~ms}^{-1}$, (inverted triangles) $10 \mathrm{~ms}^{-1}$. 


\section{Concluding remarks}

For low driving wind speed, the fires are largely unaffected by the presence of the canopy. For higher driving wind speeds there appears to be a transition from a wind-driven mode to a buoyancy-driven model near the canopy exit. This transition is characterised by a jump in flame angle, decreased rate-of-spread and an increased flame angle variability. In future, it is desirable to simulate a considerably longer domain to gain further insight into the dynamics of the fire as it adjusts to the sub-canopy wind field.

\section{References}

Dold, J, 2011, Fire spread near the attached and separated flow transition, including surge and stall behaviour. In Proc. 19th Int. Congress on Modelling and Simulation, 200-206.

Jarrin, N, Benhamadouche, S, Laurence, D and Prosser, R, 2006. A synthetic-eddy-method for generating inflow conditions for large-eddy simulations. International Journal of Heat and Fluid Flow, 27(4), 585-593.

Kanani-Suhring, F and Raasch, S, 2017, Enhanced scalar concentrations and fluxes in the lee of forest patches: A large-eddy simulation study. Boundary-Layer Meteorology, 164(1), 1-17.

Kiefer, M.T., Heilman, W.E., Zhong, S., Charney, J.J. and Bian, X., 2015. Mean and turbulent flow downstream of a low-intensity fire: Influence of canopy and background atmospheric conditions. Journal of Applied Meteorology and Climatology, 54(1), 42-57.

McGrattan, K, Hostikka, S, and Floyd, JE, 2013, Fire dynamics simulator, users guide. NIST special publication, 1019.

Mell, W, Jenkins, MA, Gould, J and Cheney, P, 2007, A physics-based approach to modelling grassland fires. International Journal of Wildland Fire, 16, 1, 1-22.

Pavlidis, D, Gorman, GJ, Gomes, JL, Pain, CC and ApSimon, H, 2010. Synthetic-eddy method for urban atmospheric flow modelling. Boundary-layer Meteorology, 136(2), 285-299.

Seto, D, Strand, TM, Clements, CB, Thistle, H and Mickler, R, 2014. Wind and plume thermodynamic structures during low-intensity subcanopy fires. Agricultural and Forest Meteorology, 198, 53-61. 